\title{
Main Theme of Feminist under Political
}

\section{thoughts}

\author{
K. K. Abithaa \\ Department of English, Nadar Saras wathi College of Arts and Science, vadapudupatti, Theni, Tamil Nadu, India \\ Email:kkabithaa191330@gmail.com
}

\begin{abstract}
A large amount of feminist writing deals with different aspects of subordination of women and about the political rights for women. Feminist like Karla Marx and his voice for those women's who are under the control of men. That the main thing of these type of writers who portrait how women's will get equal rights in this world. Keywords-Subordination, Political, Equal, Portrait.
\end{abstract}

\section{INTRODUCTION}

Feminist says woman marginalised peoples because women are coming under the men and especially the black women are suffering a lot. Mainly the political theme is used in Marxist feminism. That the initiator of Marxist feminism is Karla Marx .That he states "A man is more as an economic as as a political animal". Mainly we can state the class struggles in society.

\section{AIM OF TODAYS FEMINISM}

The aim and political lexis of today feminism is related to the contraposition to the Standing rules, norms and dogmas in society. In this sense feminism is identified by the desire to acknowledge the women's rights and equality, as well the different attitude towards the perception of women. That the word Feminism is used for the first time in English in the end of the XVII century. During the particular historical period, the social states of women was unenviable many feminist writers points of intersection to other political ideologies ex these are Liberal Feminism, Marxist Feminism uses the views, ideas and beliefs of social development from other political ideologies.

\section{WOMENS GET POWER IN MODERN DAYS}

That in society as in Modern days women's get a power to get inside the circle of politicise that it's not only the rights which was given for women that all feminist were expecting much from the society as all women's need to get equal rights as equal to the men. Nowadays women's are going to job and those jobs are equal to men that the jobs are in factories, sweetshop. Olden days women should inside the home like a slave but now women came out from that world because these feminist change the society by their writings. And still now also some of the men said that "womens are week".

\section{CONCLUSION}

According to all the feminist that they talk about the rights for women's "defined as Feminism is getting equal rights in all sphere" like property rights, voting rights, etc. As same as that women's get a rights in political but there is still remaining the gender and class struggle in the society not only this. The women's are under the control of men by the race.

\section{REFERENCES}

Feminist Political Thought - Political Science - Oxford Bibliographies - obo. (2019). Retrieved from https://www.oxfordbibliographies.com/view/document/ob o-9780199756223/obo-9780199756223-0234.xml 